Vincent Brown, Tacky's Revolt: The Story of an Atlantic Slave War. Cambridge MA:

Harvard University Press, 2020. viii +320 pp. (Cloth US\$35.00)

On April 7, 176o, a slave revolt broke out in the northeast parish of St. Mary, Jamaica. Its ringleaders came from the Gold Coast in West Africa and, at its peak, the revolt involved around 400 rebels. More than a month later, on May 25, there was another insurrection in the western parish of Westmoreland. These two uprisings were the beginning of a war that lasted 18 months and resulted in 500 Blacks being killed or executed and 500 more transported. In this extraordinary book, Vincent Brown examines what became known as Tacky's Revolt.

Brown is particularly good in dealing with the African background to the uprisings. He notes the significance of the wars on the Gold Coast that led to the buildup of large African armies and the use of firearms. Those developments meant that significant numbers of enslaved people in Jamaica came from this region, many of whom were soldiers. Known generically as Coromantees, they were highly prized by the Jamaican planters but also feared since the planters believed that they were prone to rebellion. The planters had good reason to be concerned: Coromantees were involved in the early slave rebellions of the seventeenth century and even more significantly in the larger outbreaks of the eighteenth.

Using highly sophisticated graphics, Brown documents the outbreak of Tacky's Revolt. The rebels killed Whites but also non-Whites who opposed them and made use of obeah practitioners to generate ideas about the rebels' invulnerability to any attacks by the Whites. As Brown points out, the rebels' patterns of attack were linked to precedents on the Gold Coast and reflected an attempt at territorial and political control. Interestingly, 40 percent of the captured rebels were women. The response of the government was immediate and brutal: the governor declared martial law and made use of all the armed forces on the island, including the Navy, and, importantly, the Maroons. Creating what Brown calls "a landscape of terror" (p. 156), the authorities crushed the rebellion. But as he suggests, Tacky's Revolt "was just one episode in a much larger Coromantine war" (p. 131.)

The insurrection in Westmoreland in May was even more serious than the April uprising in St. Mary, in part because the rebels' strategy drew on African experience with forest warfare and mountaineering. Brown argues that the rebels also adapted to Jamaica's political geography. Their attack was timed for the Whitsun holidays, when the planters' attentions would be elsewhere. The rebels created a mountain retreat and seemed to have had conflicting ideas of Black freedom: on the one hand, creating an independent Maroon village and, 
on the other, emulating the coastal trading states of West Africa. Although most of the rebels were captured or killed, a group headed by a leader named Simon carried on attacking estates and Whites in the neighboring parishes for months. This gang had probably learned many of their extraordinary skills in Africa but as Brown points out, their African background was only part of the story: "the Coromantee War was more than an expression of African heritage; it was the outcome of black military intellect in Jamaica" (p. 205).

The Coromantee War had lasting consequences. The practice of obeah was criminalized and there were significant restrictions on the free people of color. White solidarity was regarded as the key to the planters' security. The planter historian Edward Long argued that the insurrections were caused by Africans; as a result, he maintained that a native-born population would be more "tractable." For Brown, then, the turbulence of the slave war "indirectly helped to nurture the emerging antislavery movement" (p. 228). The insurrections helped to shift policy toward ameliorating the conditions of the enslaved and ultimately led to the abolition of the slave trade, and emancipation itself.

In a fascinating epilogue, Brown points out that in 1807 the enslaved were teaching the story of the 176 os outbreaks to new African arrivals. This was in Brown's terms "an oppositional political history taught and learned on Jamaican plantations - a radical pedagogy of the enslaved" (p. 242). Tacky's Revolt was therefore much more than the story of the Coromantees. Brown argues that "recognizing slave revolt as a species of warfare is the first step toward a new cartography of African slavery" (p. 4). This well-written, beautifully illustrated, and incredibly well-researched book points the way forward toward a new cartography linking Europe, Africa, and the Americas and toward the future study of slave revolts and resistance.

\section{Gad Heuman}

Department of History, University of Warwick, Coventry, England, U.K. g.j.heuman@warwick.ac.uk 